\title{
IMPACT OF COMMERCIAL AND INVESTMENT ACTIVITIES IN AGRICULTURE ON LOCAL DEVELOPMENT
}

\author{
Aleksa Dokićl, Dubravka Užar ${ }^{2}$, Goran Petković ${ }^{3}$, Dragan Stojković ${ }^{4}$ \\ *Corresponding authorE-mail: dubravka.uzar@polj.uns.ac.rs
}

\begin{abstract}
A R T I C LE IN F O
A B S T R A C T

Review Article

Received: 05 May 2020

Accepted: 24 May 2020

The main idea in this paper was to investigate how agriculture and processing sectors are connected through commercial activity, and how they influence municipal economic development in Serbia. This was examined doi:10.5937/ekoPolj2002569D

UDC 339:330.322:[338.43

Keywords:

commercial activities in agriculture, investments in agriculture, agricultural subsidies, local development, Serbia through the influence of relevant non-price structural factors related to agricultural and processing sector on the ratio between agricultural product procurement and overall agricultural production. The focus was placed on agricultural investments and subsidies. A multi regression model was developed based on hard data provided by SORS and SBRE on a municipal level in Serbia. The analysis confirmed the relation between agricultural commercial activity and municipal level of economic development. In addition, important findings concerning

JEL: Q02, Q13, R11, R12 municipal investment and agricultural subsidies allocation have been provided as well.
\end{abstract}

(C) 2020 EA. All rights reserved.

\section{Introduction}

Agriculture represents one of the foundations of Serbian economy (Vukadinovic et al., 2017). The country has come a long way in the last century in terms of industrial expansion, but the agriculture remains one of the key components in the national GDP, with the total share ranging between $6 \%$ and $7 \%$ in the last decade. These figures

1 Aleksa Dokić, M.Sc. M.Sc, Teaching Assistant, University of Belgrade - Faculty of Economics, Kamenička 6, 11000 Belgrade, Serbia, Phone: +381 (11) 3021 106, E-mail: aleksa.dokic@ekof.bg.ac.rs, ORCID ID (https://orcid.org/0000-0003-1274-3947)

2 Dubravka Užar, MAgrEC, Teaching Assistant, University of Novi Sad, Faculty of Agriculture, Trg Dositeja Obradovića 8, 21000 Novi Sad, Serbia, Phone: + 381 (21) 4853 274, E-mail: dubravka.uzar@polj.uns.ac.rs, ORCID ID (http://orcid.org/0000-0002-0593-7383)

3 Goran Petković, PhD, Full Professor, University of Belgrade - Faculty of Economics, Kamenička 6, 11000 Belgrade, Serbia, Phone: +381 (11) 3021 106, E-mail: goran. petkovic@ekof.bg.ac.rs, ORCID ID (https://orcid.org/0000-0001-7304-9751)

4 Dragan Stojković, PhD, Full Professor, University of Belgrade - Faculty of Economics, Kamenička 6, 11000 Belgrade, Serbia, Phone: +381 (11) 3021 130, E-mail dragan. stojkovic@ekof.bg.ac.rs,ORCID ID (https://orcid.org/0000-0003-2636-8682)

http://ea.bg.ac.rs 
are significantly higher compared to EU-28 counterparts. This can be attributed to the abundant natural resources and favourable climate conditions for agricultural production (Užar \& Radojević, 2019). Serbian agricultural sector is slowly going through the market concentration phase. According to the data provided by Statistical Office of the Republic of Serbia (SORS), compared to the data from 2012, 2018 has seen an increase in the total used arable land by $1.1 \%$. This is coupled with a significant drop in the overall number of farms by $9.9 \%$. As a consequence, the average farm size increased by $13.5 \%$. Larger fields allow for higher productivity and yields, creating the room for potential investments. Overall, $80 \%$ of farms possesses some form of mechanisation, although most of which is older than 20 years $(86 \%)$.

Serbia possesses around 5.2 million ha of arable land, of which $67.1 \%$ is economically utilized. According to OECD, wheat and maize are one of the most globally cultivated crops, alongside sugar can, rice and soybean. In Serbia, wheat and maize represent two most commonly cultivated agricultural products, with the total farmland share of $25.89 \%$ and $18.56 \%$, respectively. This implies that almost half of the used arable land is used for the cultivation of these two crops. Many authors used maize (Jones et al., 2003; Karp \& McCalla, 1983; Lin et al., 2003) and wheat (Dorosh \& Salam, 2008; Paarlberg \& Abbott, 1986) as relevant denominators of agricultural production. Following this logic, and since our empirical data are related to the Serbian market, our research revolved around the aggregated data regarding the production of these two crops.

Rural area constitutes the majority of Serbian territory (85\%), where around $48 \%$ of active rural population works in agriculture (Agriculture and Rural Development Strategy of the Republic of Serbia for the period 2014-2024.). This is also reflected on the fact that agriculture is the important contributor to the total income of rural population (Zarić et al., 2016). In developing countries, amongst which Serbia, agricultural sector contributes more to the overall GDP per capita, compared to developed countries (Savic et al., 2016). Although rural areas are heavily dependent on primary production (Vukadinovic et al., 2017), cross-industrial effects on overall rural and national growth are also present (J. P. Brown et al., 2014). This effect is especially present in the processing sector (Savic et al., 2016), since agricultural products represent one of the most significant inputs for processing industry. These effects are transferred amongst different sectors through trade (Karp \& McCalla, 1983). This is not surprising, since the development of commerce and agriculture has always been interlinked throughout history, even from the earliest civilizations. Thus, many authors focused their research on specific intersections of these two sectors, such as international trade (Bessler \& Babula, 1987; Goldberg \& Knetter, 1995; Kristjanson, 1967; Lin et al., 2003), national purchasing (J. P. Brown et al., 2014; Tudor \& Balint, 2006; Vukadinovic et al., 2017) and lately, e-commerce (Lu \& Perreau, 2005; Nadarajan \& Ismail, 2011).

Local discrepancies can have a significant influence on a national agricultural market (Birthal et al., 2011; Nganje et al., 2004). This is also the case with Serbia, where significant socio-economic (Mijačić \& Paunović, 2011; Stojković et al., 2018) and geographic (Manić et al., 2013) differences exist. Drawing upon the aforementioned correlation 
between agricultural and processing sector (Savic et al., 2016), the main idea in this paper was to investigate how these sectors are connected through commercial activity, and how they influence municipal economic development in Serbia. This was examined through the influence of relevant non-price structural factors related to agricultural and processing sector on the ratio between agricultural product procurement and overall agricultural production. Regarding relevant non-price structural factors, contemporary literature analysed the effects of investments (Anderson et al., 1994; Mogues \& Olofinbiyi, 2020), employment (Tudor \& Balint, 2006) and subventions (Ildikó et al., 2009). In this paper the focus was placed on investments and subsidies, as confirmed means of economic development (Cicea et al., 2010), whereas employment was observed separately, in the context of the overall municipal level of development. In order to implement a municipal level of analysis, a drill-down approach was used on hard data for Serbia, as a European transition economy, provided by the Serbian Business Registers Agency (SBRA) and Statistical Office of the Republic of Serbia (SORS).

The structure of this paper reflects the logic applied to the research process. First, relevant literature was analysed to develop research hypotheses. After that, an overview of the implemented methodology is provided, followed by model development and the presentation of derived results. Afterwards, a discussion of the research findings is provided, coupled with the analysis of practical economic implication. Concluding remarks are related to the research topic outlook, along with potential future research directions.

\section{Literature review}

Strong and modernised agriculture is one of the backbones of a nation's economic growth and prosperity (Nganje et al., 2004). Well-developed agricultural sector is characterised by high levels, as well as growth rates of labour productivity, which both lead to higher levels of export on a national level, and economic (rural) development on a local level (J. P. Brown et al., 2014). In terms of macroeconomic effects, prospering, export-oriented agricultural sector positively influences the reduction of a national twin deficit (Eldemerdash et al., 2014; Mudassar et al., 2013). Effects of agricultural development are also felt on the local level, where they strongly influence the level of municipal disparities within a country (Birthal et al., 2011). High share of agriculture in national GDP is not always a positive indicator, though. In developing countries, including Serbia, the correlation between GVA in agricultural sector on GDP per capita is much higher compared to developed countries (Savic et al., 2016). Therefore, it is vital to have a well-developed, efficient national agro-business.

Agricultural production is the key denominator of national and global food security (Iganiga \& Unemhilin, 2011). Having in mind the dependence of agricultural output on various internal and external factors (Boserup, 1975; Fisher et al., 2012), its effect on agricultural sector as a whole is complex, significant and oftentimes unpredictable. This is especially true for economies in transition, which are even more susceptible to unpredictable market fluctuations (Desai, 1998). The negative effect of volatility and unpredictability is felt the most on a local, municipal level. 
The development and growth of agricultural and commercial sectors is co-dependent, especially for economies still going through transition. Extensive research into agrocommercial connections exists, focusing both on international aspect (Bessler \& Babula, 1987; Goldberg \& Knetter, 1995; Kristjanson, 1967; Lin et al., 2003), as well as national perspective (J. P. Brown et al., 2014; Petrick \& Weingarten, 2004; Tudor \& Balint, 2006; Vukadinovic et al., 2017). Research into the effects of various ICT innovations in modern trade is also gaining in momentum (Lu \& Perreau, 2005; Nadarajan \& Ismail, 2011). Within the existing literature, the analysis of agro-commercial relations is mainly related to investigating different effects on agricultural product purchasing (Fayçal \& Ali, 2016; Petrick \& Weingarten, 2004; Vukadinovic et al., 2017). Certain authors, such as Brown (2014), do provide a regional analysis of the topic, going into effects on a local level, but these efforts also fall short in terms of a specific focus on transition economies. Drawing upon this, in this research a link between agricultural and commercial sector was modelled through the introduction of a synthetic indicator depicting agricultural product purchase intensity. Therefore, we develop the following hypothesis:

$\mathrm{H}_{1}$ : Commercial activity based on agricultural products positively influences municipal economic level of development.

Commercial activity based on agricultural products was modelled by proposing an indicator calculated as a ratio between agricultural product purchasing and the production of those specific products. This ratio represents a municipal agricultural product purchase intensity, which in itself should possess informational value on municipal level of economic development.

When analysing in detail papers investigating agricultural inter industrial influences, two predominant research patterns emerge, depending on whether price or non-price factors are considered (Chhibber, 1988). First research angle focuses on observing price-related factors, such as price incentives (Thiele, 2003) and policies (Dorosh \& Salam, 2008; Fulginiti \& Perrin, 1993). These research efforts adopt a macroeconomic perspective, analysing either international markets (Bessler \& Babula, 1987; Lin et al., 2003; Thiele, 2003) or aggregated national market situations (Dorosh \& Salam, 2008; Park \& Fortenbery, 2007). The second research approach is based on analysing non-price agricultural factors of influence. Non-price factors have a profound influence on local agricultural development (Birthal et al., 2011; J. D. Brown, 2009; Nganje et al., 2004), oftentimes more than price-related factors (Thiele, 2003). In this sense, authors observed investments (Cicea et al., 2010), subsidies (Ildikó et al., 2009) and employment (Tudor \& Balint, 2006). Since the close link between agriculture and processing industry has already been identified (Savic et al., 2016), this paper focuses on analysing influence of identified structural non-price factors in the context of two aforementioned industries on proposed agricultural product purchase ratio. This allows for a comprehensive, theoretically-sound analysis of agricultural inter-industrial effects, modelled through commercial activity on municipal economic development. 
One of the basic Government instruments of agricultural policy entails decisions on subsidy allocation to agricultural producers. The purpose of the subsidies is to bridge the gap between the relatively high costs of production and the relatively low prices of agricultural products in the market. Accordingly, the producers are economically motivated to stay on their farms and continue with the production to ensure food security for the population. Subsidies themselves represent a sort of investment activity, with wider, societal considerations (Ildikó et al., 2009). Therefore, it is important to consider the effect of subsidies on the sale of agricultural products

$\mathrm{H}_{2}$ : Municipal subsidy allocation has a positive effect on municipal agricultural commercial activity.

Effective and efficient investment policy is vital in ensuring a long-term growth of the agro-business (Anderson et al., 1994). Higher levels of well-planned investments lead to higher levels of agricultural sector development (Cicea et al., 2010). Optimal investment allocation is especially important for Serbia, dealing with limited financial resources. Since investment planning on a municipal level is vital for the development of local and national markets, the following research hypothesis is derived

$\mathrm{H}_{3}$ : Municipal investment allocation has a positive effect on municipal agricultural commercial activity.

In the context of aforementioned inter industrial effects, the link between agricultural and processing sector development has to be accounted for (Savic et al., 2016). In this sense, third hypothesis can be divided into two corresponding sub hypotheses.

$\mathrm{H}_{3.1}$ : Municipal investment share in agricultural sector has a positive effect on municipal agricultural commercial activity.

$\mathrm{H}_{3,2}$ : Municipal investment share in processing sector has a positive effect on municipal agricultural commercial activity.

The following chapter is dedicated to explaining the implemented research methodology, followed by the presentation of derived results, along with the corresponding discussion.

\section{Methodology}

For the purposes of the research, hard data provided by the Serbian Business Registers Agency (SBRA) and Statistical Office of the Republic of Serbia (SORS) were used. Data on the municipal purchasing and production of agricultural products were provided by SORS. Data on wheat and maize purchasing and production were aggregated and used as proxies for municipal agricultural products, as two most cultivated crops in Serbia. The chosen unit of observation was municipality, as the key administrative unit in Serbia. Data regarding investments in agricultural and processing sectors were also provided by SORS. Data on agricultural subsidies on a municipal level were given by SBRA. Observation year was 2017. The analysed sample included 145 municipalities with registered purchase of agricultural products. Detailed overview of model variable definitions is provided in Table 1. 
Table 1. Definitions of model variables

\begin{tabular}{|c|c|c|}
\hline Variable & $\begin{array}{c}\text { Unit of } \\
\text { Measure }\end{array}$ & Definition \\
\hline $\begin{array}{l}\text { Agricultural } \\
\text { product purchasing }\end{array}$ & Tons & $\begin{array}{l}\text { Purchase of agricultural products refers to agricultural products } \\
\text { purchased or taken over directly from family holdings by } \\
\text { agricultural, trade, industrial and other organizations, for the } \\
\text { purpose of further sale or processing (Statistical Yearbook of RS, } \\
\text { 2019). }\end{array}$ \\
\hline $\begin{array}{l}\text { Agricultural } \\
\text { production of major } \\
\text { crops }\end{array}$ & Tons & $\begin{array}{l}\text { Agricultural production is the output of production of plants } \\
\text { and livestock products, fish farming, poultry farming, bees, or } \\
\text { other forms of agricultural production, which is carried out on } \\
\text { agricultural land, as well as on other land or construction unit } \\
\text { located on the territory of the Republic of Serbia }\end{array}$ \\
\hline $\begin{array}{l}\text { Municipal } \\
\text { agricultural product } \\
\text { purchase intensity }\end{array}$ & $(\%)$ & $\begin{array}{l}\text { Ratio of municipal agricultural products purchasing and municipal } \\
\text { agricultural production }\end{array}$ \\
\hline $\begin{array}{l}\text { Share of municipal } \\
\text { agricultural } \\
\text { subsidies }\end{array}$ & $(\%)$ & $\begin{array}{l}\text { According to the Law on Subsidies in Agriculture and Rural } \\
\text { Development of the Republic of Serbia, we can define four types } \\
\text { of incentives: Direct payments, Rural development measures; } \\
\text { Special incentives; Credit support (Official Gazette of the RS, } \\
\text { 2016). Subsidies allocated to the municipal level are the amounts } \\
\text { of incentives allocated to the territorial level of each selected } \\
\text { municipality in particular. The share of municipal agricultural } \\
\text { subsidies is the share of this subsidies in total municipal subsidies } \\
\text { from aforementioned sources. }\end{array}$ \\
\hline $\begin{array}{l}\text { Share of municipal } \\
\text { investments in } \\
\text { agricultural sector }\end{array}$ & $(\%)$ & $\begin{array}{l}\text { The share of investments in agriculture in total investments } \\
\text { in the reporting year present the value of effectively finalized } \\
\text { constructions, production or acquisition of facilities, equipment } \\
\text { and other fixed assets, disregarding whether these investments } \\
\text { were accomplished and whether they were paid out (excluding } \\
\text { revaluation)* }\end{array}$ \\
\hline $\begin{array}{l}\text { Share of municipal } \\
\text { investments in } \\
\text { processing sector }\end{array}$ & $(\%)$ & $\begin{array}{l}\text { The share of investments in processing sector in total investments } \\
\text { in the reporting year present the value of effectively finalized } \\
\text { constructions, production or acquisition of facilities, equipment } \\
\text { and other fixed assets, disregarding whether these investments } \\
\text { were accomplished and whether they were paid out (excluding } \\
\text { revaluation) }\end{array}$ \\
\hline
\end{tabular}

*Investments in agriculture, forestry and fishing includes: crop and animal production, hunting and related service activities, investments in forestry and logging and investments in fishing and aquaculture.

The general form of the regression model is:

$$
Y_{i}=\beta_{0}+\beta_{1} X_{1 i}+\beta_{2} X_{2 i}+\ldots+\beta_{p} X_{p i}+\varepsilon_{i}
$$

Where $Y_{i}$ is the dependent variable, $X_{p i}$ is the independent variables, $\beta_{p}$ is the regression coefficients, $\varepsilon_{i}$ is the stochastic error, $i \mathrm{i}[1 \ldots, \mathrm{n}]$ and $p \hat{\mathrm{I}}[1 \ldots, \mathrm{n}]$.

In order to make valid inferences from regression, the residuals of the regression should follow a normal distribution. A normal Predicted Probability (P-P) plot has 
been examined and the residuals are normally distributed. Homoscedasticity refers to whether these residuals are equally distributed, or whether they tend to bunch together at some values, and at other values, spread far apart. This assumption has been confirmed by plotting the predicted values and residuals on a scatter plot. So, the residuals are normally distributed and homoscedastic.

To test the assumption that residuals are independent (or uncorrelated), the DurbinWatson statistic has been used. This statistic can vary from 0 to 4. Assumption will be confirmed if this value is close to 2. The Durbin-Watson statistic showed that this assumption had been met, as the obtained value was close to 2 (DW of 1.57). The validity of the defined model is also confirmed in terms of potential multicollinearity. Since the Tolerance indicator value is higher than .1, and VIF indicator value is lower than 10 we can conclude that the model assumption of non-multicollinearity has not been violated.

\section{Results and discussion}

As explained in the theoretical part of the paper, the guiding research thought was to encompass structural, non-price factors from agricultural and processing sector, analyse their influence on municipal commercial activity regarding agricultural products, and understand the effects on the overall municipal economic development. An overview of these relations is summarised in Table 3, depicting results for 145 observed municipalities in Serbia (settlements with more than one municipality were analysed aggregately).

Table 2. Descriptive municipal data (Serbia, 2017)

\begin{tabular}{|l|c|c|c|}
\hline \multicolumn{1}{|c|}{ Level of municipal development } & $\begin{array}{c}\text { Average municipal } \\
\text { agricultural product } \\
\text { purchase ratio }\end{array}$ & $\begin{array}{c}\text { Average municipal } \\
\text { share of employment in } \\
\text { agriculture }\end{array}$ & $\begin{array}{c}\text { Aggregated } \\
\text { share of } \\
\text { agricultural } \\
\text { production }\end{array}$ \\
\hline I (above national average, N=20) & $34.15 \%$ & $1.69 \%$ & $22.56 \%$ \\
\hline $\begin{array}{l}\text { II (100-80\% of national average, } \\
\text { N=34) }\end{array}$ & $27.22 \%$ & $3.15 \%$ & $33.37 \%$ \\
\hline $\begin{array}{l}\text { III (80-60\% of national average, } \\
\text { N=47) }\end{array}$ & $18.02 \%$ & $4.73 \%$ & $35.82 \%$ \\
\hline $\begin{array}{l}\text { IV (below } 60 \% \text { of national average, } \\
\text { including devastated areas, N=44) }\end{array}$ & $5.19 \%$ & $2.27 \%$ & $8.25 \%$ \\
\hline $\begin{array}{l}\text { The municipalities of Kosovo and Metohija were not included in the analysis due to the lack of data. } \\
\text { Settlements with more than one municipality were analysed aggregately. }\end{array}$ \\
\hline
\end{tabular}

A further graphical comparison between municipal level of economic development (Figure 1) and municipal agricultural product purchase intensity (Figure 2) is also possible. 
Aggregated descriptive and graphical findings allow for some crude suggestions. It seems as if the most developed municipalities have the lowest participation of agricultural employment, as well as the highest average agricultural product purchase ratio per municipality. The lower the economic development of the municipality is, the lower the average agricultural product purchase ratio is. This implies that commercial activity is an important catalyst for agricultural, and also overall municipal development. We can conclude that the higher the share of non-traded agricultural product turnover, mainly consisting of intra organisational use and individual consumption, the lower the overall development of the municipality.

Figure 1. Municipal level of economic development (based on data by SBRE)

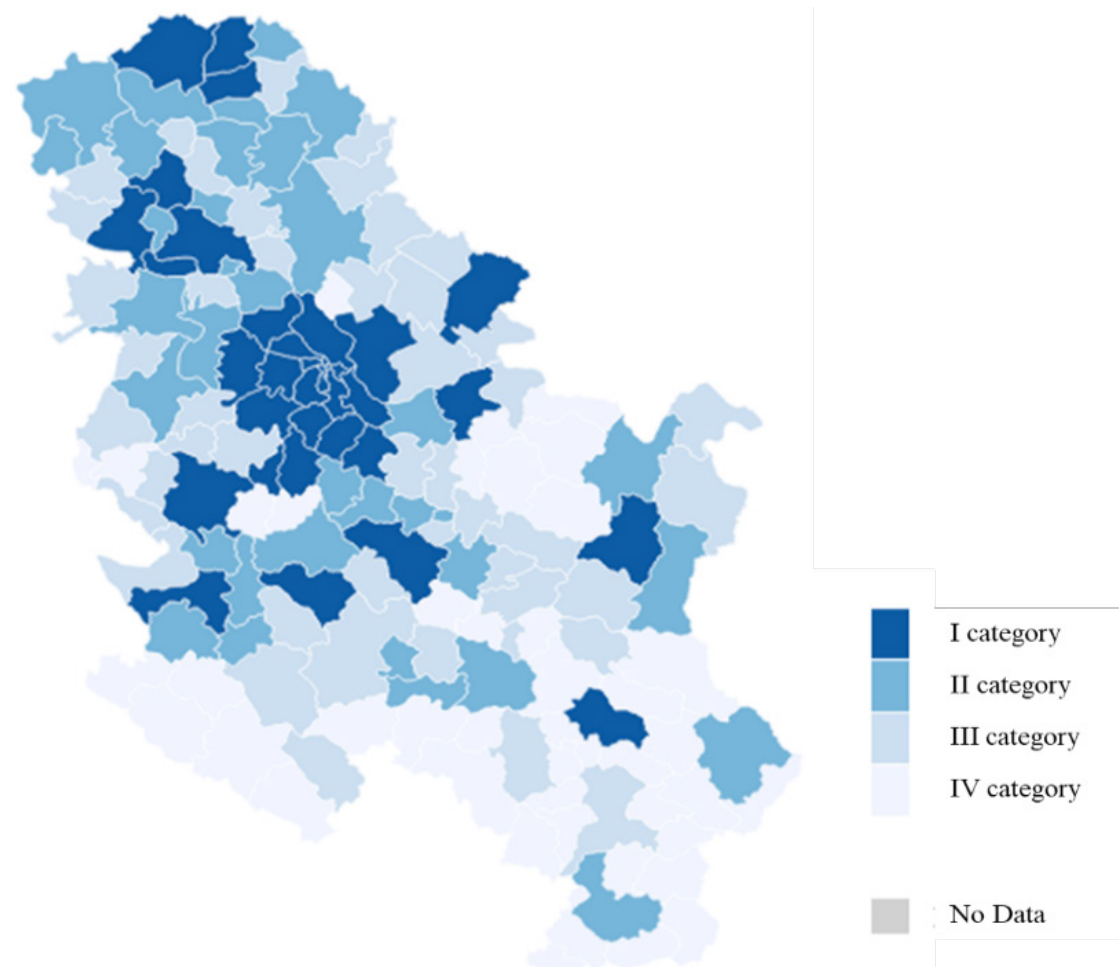

Source: Authors' calculations 
Figure 2. Municipal agricultural product purchase intensity
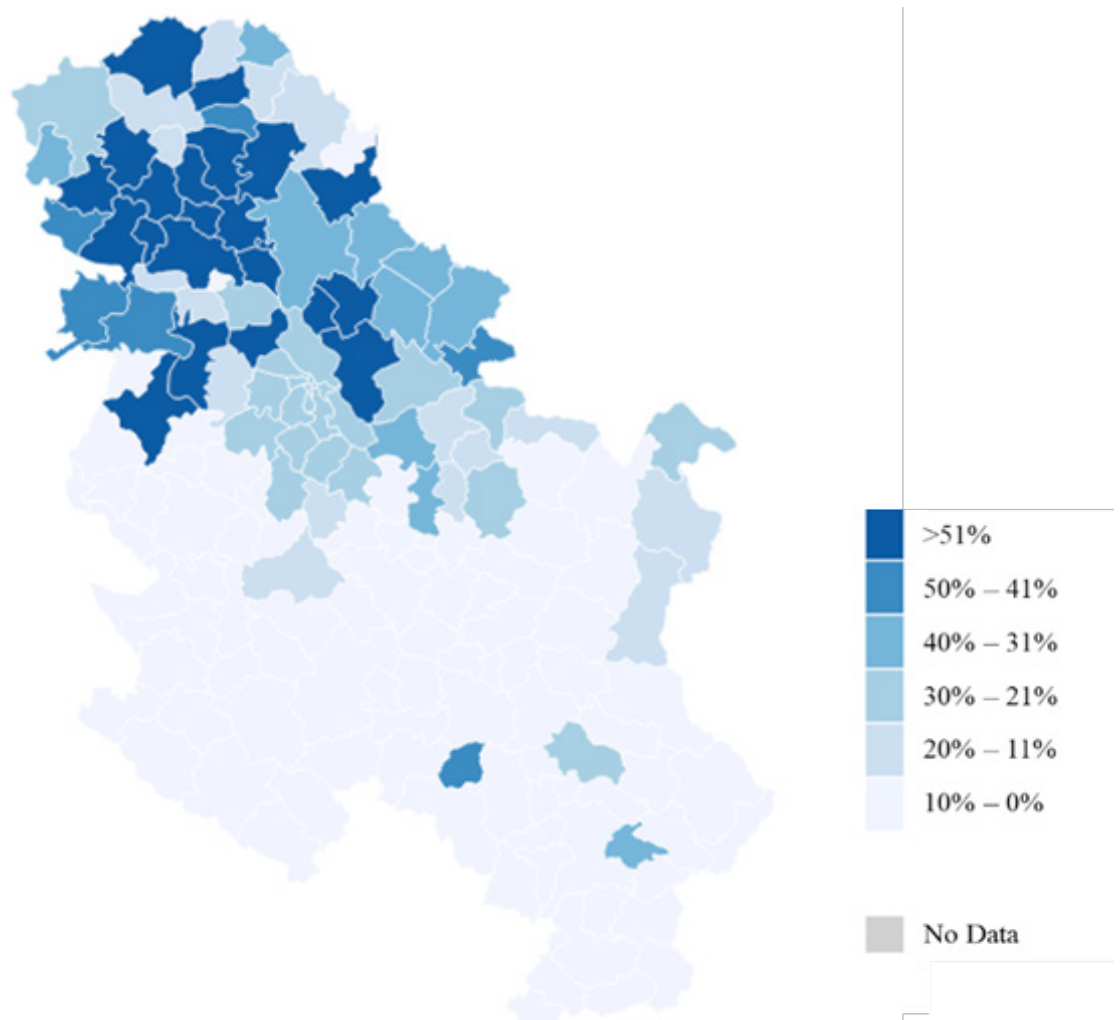

Source: Authors' calculations

In order to fully understand the relation between municipal level of development and municipal agricultural product purchase intensity, a regression model was developed. This analysis also encompassed the effect of employment share in two observed relevant sectors. This model is shown in equation 2.

$$
Z=3.310-.016 y+.051 x_{4}-.016 x_{5}+\varepsilon
$$

Obtained partial regression coefficients of relevant variables are presented in Table 3. 
Table 3. Multiple regression model depicting municipal level of economic development

\begin{tabular}{|c|c|c|c|c|c|}
\hline \multicolumn{6}{|c|}{ Coefficients $^{\mathrm{a}}$} \\
\hline \multirow{2}{*}{ Model } & \multicolumn{2}{|c|}{$\begin{array}{l}\text { Unstandardized } \\
\text { Coefficients }\end{array}$} & \multirow{2}{*}{$\begin{array}{c}\begin{array}{c}\text { Standardized } \\
\text { Coefficients }\end{array} \\
\text { Beta }\end{array}$} & \multirow{2}{*}{$\mathbf{t}$} & \multirow{2}{*}{ Sig. } \\
\hline & B & $\begin{array}{c}\text { Std. } \\
\text { Error }\end{array}$ & & & \\
\hline (Constant) & 3.310 & .216 & & 15.337 & .000 \\
\hline Agricultural product purchase ratio $(y)$ & -.016 & .003 & -.427 & -5.101 & .000 \\
\hline $\begin{array}{l}\text { Share of employment in agricultural } \\
\text { sector }\left(x_{4}\right)\end{array}$ & .051 & .025 & .179 & 2.089 & .038 \\
\hline $\begin{array}{l}\text { Share of employment in processing sector } \\
\left(x_{f}\right)\end{array}$ & -.016 & .007 & -.173 & -2.218 & .028 \\
\hline
\end{tabular}

Source: Authors' calculations

The results led to some interesting findings. First, proposed agricultural product purchase ratio $(y)$ has a positive influence on municipal level of development. Since the municipal development is observed through 4 categories on an inverted scale (category I - highest level of development, category IV - lowest level of development), we can conclude that an increase in municipal agricultural product purchase intensity of 62.5 percentage points (pp), the municipality enters a higher category of development. Second, share of employment in processing sector $\left(x_{5}\right)$ has a similar effect as the previously discussed variable, which implies that this share also has to increase by $62.5 \mathrm{pp}$ in order for the municipality to enter a higher development category. Lastly, share of employment in agriculture $\left(x_{4}\right)$ has a negative effect on municipal economic development. This is an interesting finding, which confirms that, regarding long-term economic development, high levels of agricultural employment do not yield best macroeconomic results (Savic et al., 2016). The developed model was confirmed as statistically significant using ANOVA (F-statistic of 11.964 and .000 significance) with the predictability potential of .186 .

Having confirmed the relation between agricultural commercial activity and municipal level of economic development $\left(\mathrm{H}_{1}\right)$, the next step was the development of a regression model for understanding municipal agricultural product purchase intensity. In total, 3 independent variables were observed, modelling the influence of municipal share of agricultural subsidies in all municipal subsidies $\left(x_{1}\right)$, as well as the share of investments aimed towards agricultural $\left(x_{2}\right)$ and processing $\left(x_{3}\right)$ sectors. This model is shown in equation 3 .

$$
Y=2.156+.293 x_{1}+.518 x_{2}+.236 x_{3}+\varepsilon
$$

Obtained partial regression coefficients of relevant variables are presented in Table 4. 
Table 4. Multiple regression model depicting municipal agricultural product purchase ratio

\begin{tabular}{|l|c|c|c|c|c|}
\hline \multirow{2}{*}{ Model } & \multicolumn{2}{|c|}{$\begin{array}{c}\text { Unstandardized } \\
\text { Coefficients }\end{array}$} & $\begin{array}{c}\text { Standardized } \\
\text { Coefficients }\end{array}$ & \multirow{2}{*}{ t } & Sig. \\
\cline { 2 - 5 } & B & $\begin{array}{c}\text { Std. } \\
\text { Error }\end{array}$ & Beta & & .568 \\
\hline (Constant) & 2.156 & 3.798 & & .571 \\
\hline Share of agricultural subsidies $\left(x_{1}\right)$ & .293 & .092 & .244 & 3.189 & .002 \\
\hline $\begin{array}{l}\text { Share of investments in agricultural } \\
\text { sector }\left(x_{2}\right)\end{array}$ & .518 & .149 & .267 & 3.466 & .001 \\
\hline $\begin{array}{l}\text { Share of investments in processing sector } \\
\left(x_{2}\right)\end{array}$ & .236 & .072 & .249 & 3.265 & .001 \\
\hline a. Dependent Variable: Municipal agricultural product purchase ratio $(Y)$ & & \\
\hline
\end{tabular}

Source: Authors' calculations

Presented findings indicate statistical significance of the parameter $\beta_{1}$, depicting the importance of subsidies allocation on agriculture in the developed model. It can be concluded that by increasing the share of municipal agricultural subsidies by $1 \mathrm{pp}$, municipal agricultural product purchase ratio consequently increases by .293 pp. This finding confirms the second hypothesis $\left(\mathrm{H}_{2}\right)$. Therefore, we can conclude that the higher share of subsidies in agriculture have a positive effect on the municipal agricultural product purchase intensity. Transition economies operate with significant financial limitations, therefore the use of funds, especially in the form of subsidies, must be efficient and effective. It is important to understand all positive effects of means allocation to agriculture, since inter industrial effects are also present.

The influence of municipal investment allocation was also examined. The results show that both $\beta_{2}$ and $\beta_{3}$ parameters are statistically significant. With the increase in the municipal share of investments dedicated to agriculture or processing sector of 1 $\mathrm{pp}$, the municipal agricultural product purchase ratio consequently increases by .518 pp and $.236 \mathrm{pp}$, respectively. This finding confirms both $\mathrm{H}_{3.1}$ and $\mathrm{H}_{3.2}$, which in terms confirms $\mathrm{H}_{3}$ entirely. Implications are such that higher shares of municipal investments in both agricultural and processing sector have a positive impact on municipal agrocommercial activity. This confirms the inter industrial effects of agricultural sector, and shows that a developing processing sector is also an important driver of municipal agricultural product purchase intensity, and consequently overall municipal economic prosperity. Interestingly, agricultural investments have an opposite effect compared to agricultural employment share. What this means is that in the long run, municipalities can economically prosper through capital-intensive development of agricultural sector, rather than stimulating agricultural employment, as a short-term macroeconomic "fix".

When observing the developed model as a whole, it is important to determine whether the model specification is correct. This is statistically introduced through the null hypothesis that $H_{0}: \beta_{1} \ldots \beta n=0$. The developed model has the correct specification if 
the null hypothesis is rejected. In this paper, for this purpose the analysis of variance was performed. Results from the conducted ANOVA test show that aforementioned null hypothesis regarding model specification can be rejected, which confirms statistical significance of the observed model (Table 5).

Table 5. Developed model specification analysis

\begin{tabular}{|l|l|c|c|c|c|c|}
\hline \multicolumn{7}{|c|}{ ANOVA $^{\mathrm{a}}$} \\
\hline \multicolumn{2}{|c|}{ Model } & Sum of Squares & $\mathrm{df}$ & Mean Square & $\mathrm{F}$ & Sig. \\
\hline \multirow{3}{*}{1} & Regression & 22369.209 & 3 & 7456.403 & 11.533 & $.000^{\mathrm{b}}$ \\
\cline { 2 - 7 } & Residual & 91158.730 & 141 & 646.516 & & \\
\cline { 2 - 7 } & Total & 113527.938 & 144 & & & \\
\hline
\end{tabular}

Source: Authors' calculations

Final component of the model analysis is its explanatory potential. This is depicted by $\mathrm{R}^{2}$ which show the percentage of variance of dependent variable explained by assumed independent variables (Novaković 2019). Adjusted $\mathrm{R}^{2}$ is a measure of predictive power loss in a model, or shrinkage in regression. The adjusted $\mathrm{R}^{2}$ also shows how much variance would be accounted for, had the model been derived from the population from which the sample was taken (Field, 2013). Higher values of adjusted $\mathrm{R}^{2}$ parameter indicate better model fit. The adjusted coefficient of determination shows that $18.0 \%$ of the total model variance is explained by independent variables, which is line with results from similar researches (Newman \& Tarp, 2019).

\section{Conclusion}

Agricultural sector has an important role in sustainable economic, ecological and social development of countries undergoing a transition phase, such as Serbia. Economic progress of rural areas is especially tide with the level of agricultural development. Agricultural sector is also important because of its cross-industrial, multiplicative effects. In this regard, the link between processing and agricultural sectors is of upmost importance. These effects are transferred and yield short and long term economic results through agricultural commercial activity. Drawing upon this, the focus of this paper was to investigate whether relevant municipal subsidies and investments influence the municipal purchase of agricultural products. Special attention was dedicated to local discrepancies, because of which the analysis was conducted on a municipal level.

Findings confirmed that the proposed ratio depicting municipal agricultural product purchasing intensity is a relevant factor in municipal level of economic development. This allowed for the link between municipal development and agriculture-related nonprice structural factors of influence to be modelled through commercial activity based on agricultural products. Share of agricultural subsidies was found to be significant, confirming similar previous findings (Ildikó et al., 2009). Important finding is 
that higher share of subsidies in agriculture have a positive effect on the municipal agricultural product purchase intensity. However, it should be pointed out that the use of funds, especially in the form of subsidies, must be efficient and effective. In terms of investment allocation, the existence of inter industrial effects between agricultural and processing sectors was confirmed, affirming the importance of proper, capital-intensive agro-business development (Savic et al., 2016).

It is important to note certain limitations regarding this research. First, empirical data are from a single national market. Although a relevant sample size was attained through adequate drill-down approach on a municipal level, certain national market and local specificities can somewhat influence derived results. Extension of this research topic is needed on other national and international markets. Second, developed economies, as well as developing economies differ in terms of economic growth dynamics compared to transitional economies and may exhibit different results from those presented. Third, observed municipal agricultural subsidies included only national funds allocated to municipalities. More detailed analysis including data on international subsidies is needed to gain a deeper understanding of their local implications. Fourth, data on agricultural product purchasing and production are related to wheat and maize, as most relevant crop types. Finally, data on investments are related to only one year. For a more precise analysis, a chronological perspective would be beneficial. Additionally, investments in processing sector were observed as a whole, without the extraction of the agro-business related part.

Researchers and national decision-makers would benefit from presented findings, as they represent a basis for further research into agricultural-related factors influencing municipal development.

\section{Conflict of interests}

The authors declare no conflict of interest.

\section{References}

1. Agriculture and Rural Development Strategy of the Republic of Serbia for the period 2014-2024.http://www.minpolj.gov.rs/download/strategija-poljoprivredei-ruralnog-razvoja-republike-srbije-za-period-2014-2024-godine/?script=lat (accessed 19.5.2020.)

2. Anderson, J. R., Pardey, P. G., \& Roseboom, J. (1994). Sustaining growth in agriculture: A quantitative review of agricultural research investments. Agricultural Economics, 10(2), 107-123.

3. Bessler, D. A., \& Babula, R. A. (1987). Forecasting Wheat Exports: Do Exchange Rates Matter? Journal of Business \& Economic Statistics, 5(3), 397-406. JSTOR. https://doi.org/10.2307/1391615 
4. Birthal, P. S., Singh, H., \& Kumar, S. (2011). Agriculture, economic growth and regional disparities in India. Journal of International Development, 23(1), 119131. https://doi.org/10.1002/jid.1606

5. Boserup, E. (1975). The impact of population growth on agricultural output. The Quarterly Journal of Economics, 257-270.

6. Brown, J. D. (2009). Choosing the Right Type of Rotation in PCA and EFA. JALT Testing \& Evaluation SIG Newsletter, 13(3), 20-25.

7. Brown, J. P., Goetz, S. J., Ahearn, M. C., \& Liang, C. (Kathleen). (2014). Linkages Between Community-Focused Agriculture, Farm Sales, and Regional Growth. Economic Development Quarterly, 28(1), 5-16. https://doi. org/10.1177/0891242413506610

8. Chhibber, A. (1988). Raising agricultural output: Price and nonprice factors. Finance and Development, 25(2), 44.

9. Cicea, C., Subic, J., \& Pirlogea, C. (2010). Considerations regarding investments efficiency in agriculture. Economia. Seria Management, 13(2), 321-331.

10. Desai, P. (1998). Macroeconomic fragility and exchange rate vulnerability: A cautionary record of transition economies. Journal of Comparative Economics, 26(4), 621-641.

11. Dorosh, P., \& Salam, A. (2008). Wheat Markets and Price Stabilisation in Pakistan: An Analysis of Policy Options. The Pakistan Development Review, 47(1), 71-87. https://doi.org/10.30541/v47i1pp.71-87

12. Eldemerdash, H., Metcalf, H., \& Maioli, S. (2014). Twin deficits: New evidence from a developing (oil vs. non-oil) countries' perspective. Empirical Economics, 47(3), 825-851.

13. Fayçal, M., \& Ali, H. M. (2016). Economic Growth and Government Subventions for Agriculture Sector in Algeria: An ARDL Model. Arab Economic and Business Journal, 11(2), 105-114. https://doi.org/10.1016/j.aebj.2016.10.001

14. Fisher, A. C., Hanemann, W. M., Roberts, M. J., \& Schlenker, W. (2012). The economic impacts of climate change: Evidence from agricultural output and random fluctuations in weather: comment. American Economic Review, 102(7), 3749-60.

15. Fulginiti, L. E., \& Perrin, R. K. (1993). Prices and Productivity in Agriculture. The Review of Economics and Statistics, 75(3), 471-482. JSTOR. https://doi. org/10.2307/2109461

16. Goldberg, P., \& Knetter, M. (1995). Causes and Consequences of the Export Enhancement Program for Wheat (No. w5359; p. w5359). National Bureau of Economic Research. https://doi.org/10.3386/w5359

17. Iganiga, B. O., \& Unemhilin, D. O. (2011). The impact of federal government agricultural expenditure on agricultural output in Nigeria. Journal of Economics, $2(2), 81-88$. 
18. Ildikó, K. Z., Csaba, D. I. B., László, D. P., \& Tímea, K. (2009). The effect of the foreign capital and European subventions on the competitiveness of the Hungarian agribusiness' enterprises in the last 15 years. 113th EAAE Seminar "A Resilient European Food Industry and Food Chain in a Challenging World”, 15.

19. Jones, P. C., Kegler, G., Lowe, T. J., \& Traub, R. D. (2003). Managing the SeedCorn Supply Chain at Syngenta. Interfaces, 33(1), 80-90. https://doi.org/10.1287/ inte.33.1.80.12718

20. Karp, L. S., \& McCalla, A. F. (1983). Dynamic Games and International Trade: An Application to the World Corn Market. American Journal of Agricultural Economics, 65(4), 641-650. JSTOR. https://doi.org/10.2307/1240451

21. Kristjanson, R. L. (1967). Problems and Prospects of Canadian Wheat Sales to China and the USSR. Journal of Farm Economics, 49(5), 1345-1351. JSTOR. https://doi.org/10.2307/1237025

22. Law on Subsidies in Agriculture and Rural Development (2016)., Official Gazette of RS, no. 10/2013, 142/2014, 103/2015, 101/2016, Belgrade, Republic of Serbia, https://www.paragraf.rs/propisi/zakon_o_podsticajima_u_poljoprivredi_i ruralnom_razvoju.html (accessed 10.4.2020.)

23. Lin, W., Price, G. K., \& Allen, E. W. (2003). StarLink: Impacts on the U.S. corn market and world trade. Agribusiness, 19(4), 473-488. https://doi.org/10.1002/ agr. 10075

24. Lu, N., \& Perreau, S. (2005). Sustainable agriculture mobile commerce (SamCom)extending the rural grocery supply chain through m-commerce. TENCON 20052005 IEEE Region 10 Conference, 1-6.

25. Manić, E., Popović, S., \& Molnar, D. (2013). Regional Disparities and Regional Development: The Case of Serbia. Mitteilungen Der Österreichischen Geographischen Gesellschaft, 154, 191-211. https://doi.org/10.1553/ moegg154s191

26. Mijačić, D., \& Paunović, B. (2011). Regional disparities in Serbia. Ekonomika Preduzeća, 59(7-8), 379-389.

27. Mogues, T., \& Olofinbiyi, T. (2020). Budgetary influence under information asymmetries: Evidence from Nigeria's subnational agricultural investments. World Development, 129, 104902. https://doi.org/10.1016/j.worlddev.2020.104902

28. Mudassar, K., Fakher, A., Ali, S., \& Sarwar, F. (2013). Validation of twin deficits hypothesis: A case study of Pakistan. Universal Journal of Management and Social Sciences, 3(10), 33-47.

29. Nadarajan, S. V., \& Ismail, R. (2011). E-Commerce framework to improve rural agriculture sector in Cambodia. International Conference on E-Business, Management and Economics, 25, 287-291.

30. Newman, C., \& Tarp, F. (2019). Shocks and agricultural investment decisions. Food Policy, 101810. https://doi.org/10.1016/j.foodpol.2019.101810 
31. Nganje, W. E., Bangsund, D. A., Leistritz, F. L., Wilson, W. W., \& Tiapo, N. M. (2004). Regional Economic Impacts of Fusarium Head Blight in Wheat and Barley. Review of Agricultural Economics, 26(3), 332-347. https://doi.org/10.1111/j.14679353.2004.00183.x

32. Paarlberg, P. L., \& Abbott, P. C. (1986). Oligopolistic Behavior by Public Agencies in International Trade: The World Wheat Market. American Journal of Agricultural Economics, 68(3), 528-542. JSTOR. https://doi.org/10.2307/1241538

33. Park, H., \& Fortenbery, T. R. (2007). The Effect of Ethanol Production on the U.S. National Corn Price. Proceedings on NCCC-134 Conference on Applied Commodity Price Analysis, Forecasting and Market Risk Management, 18.

34. Petrick, M., \& Weingarten, P. (2004). Institutional factors influencing agricultural sales of the individual farmers in Romania. The Role of Agriculture in Central and Eastern European Rural Development: Engine of Change or Social Buffer?, 238.

35. Savic, L., Boskovic, G., \& Micic, V. (2016). Serbian agro-industry: Potentials and perspectives. Ekonomika Poljoprivrede, 63(1), 107-122. https://doi.org/10.5937/ ekoPolj1601107S

36. Statistical Yearbook of the Republic of Serbia (2019), Statistical Office of the Republic of Serbia (SORS) https://publikacije.stat.gov.rs/G2019/Pdf/G20192052. pdf (accessed 10.4.2020.)

37. Stojković, D., Manić, E., Bogetić, Z., \& Dokić, A. (2018). Regional Retail Sector Development in Serbia-Key Performance and Development Indicators' Gap. Economic Themes, 56(3), 335-356.

38. Thiele, R. (2003). Price Incentives, Non-price Factors and Agricultural Production in Sub-Saharan Africa: A Cointegration Analysis. African Development Review, 15(2-3), 425-438. https://doi.org/10.1111/j.1467-8268.2003.00079.x

39. Tudor, M., \& Balint, B. (2006). Off-farm Employment and Agricultural Sales: Evidence from Romania. Post-Communist Economies, 18(2), 243-260. https://doi. org/10.1080/14631370600620012

40. Užar, D., \& Radojević, V. (2019). THE IMPORTANCE OF AGRICULTURE IN FORMING GROSS VALUE ADDED IN SERBIA IN THE PERIOD OF 20082017. Economics of Agriculture, 66(4), 1091-1105. https://doi.org/10.5937/ ekoPolj1904091U

41. Vukadinovic, P., Damnjanovic, A., \& Dimitrijevic, L. (2017). Analysis of the sales and incomes between different categories of agricultural products. Ekonomika Poljoprivrede, 64(1), 157-170. https://doi.org/10.5937/ekoPolj1701157V 